\title{
THE EFFECT OF METHAMPHETAMINE ON BIOTRANSFORMATION OF ETHANOL: PILOT STUDY
}

\author{
${ }^{1,2}$ Zendulka, O. - ${ }^{1,2}$ Sabová, M. - ${ }^{1,2}$ Juřica, J. $-{ }^{3}$ Machalíček, M. - ${ }^{3}$ Švéda, P. - \\ ${ }^{3}$ Farková, M. - ${ }^{1}$ Šulcová, $A$.
}
${ }^{1}$ Masaryk University in Brno, Central European Institute of Technology, Experimental and Applied Neuropsychopharmacology research group,
${ }^{2}$ Masaryk University in Brno, Faculty of Medicine, Department of Pharmacology,
${ }^{3}$ Masaryk University in Brno, Faculty of Science, Department of Chemistry

Methamphetamine is one of the most popular recreational drugs in Central Europe and is often combined with ethanol. Various interactions between these two substances have been described including the influence of administered ethanol on biotransformation of methamphetamine. The aim of the present study was to describe the opposite effect the influence of methamphetamine on biotransformation of ethanol in rats. Methamphetamine was administered for 10 days $(10 \mathrm{mg} / \mathrm{kg} / \mathrm{day})$ i.p. and ethanol was delivered as an intragastric bolus $(2 \mathrm{~g} / \mathrm{kg})$ on the $10^{\text {th }}$ day of experiment to both methamphetamine administered rats and control animals. The pharmacokinetic experiment on the whole animal was performed and plasma samples were drawn at the $40^{\text {th }}, 120^{\text {th }}, 210^{\text {th }}$ and $300^{\text {th }}$ minute after ethanol administration.

Ethanol plasmatic levels reached significantly lower values in the $40^{\text {th }}$ and $120^{\text {th }}$ interval when compared to controls. Differences were insignificant in the last two intervals. Our results suggest that chronic methamphetamine administration induces ethanol biotransformation. We suppose that this effect is caused by induction of alcohol dehydrogenase metabolic activity or by allosteric interaction of methamphetamine and this enzyme. More studies have to be conducted to confirm or disprove our hypothesis.

Keywords: methamphetamine - ethanol - biotransformation - interaction - rat

\section{INTRODUCTION}

Substance abuse is as old as mankind, and brings together health and social problems affecting both the abuser and the society as well. Drugs of abuse are miscellaneous substances eliciting different biologic effects, and their misuse is usually region-specific due to differences in their availability, legislation, and social conditions in the specific area. One of the most popular recreational drugs besides cannabis in the Central Europe 
is methamphetamine (METH). METH abuse in the Czech Republic has a long tradition, as amphetamines serving as a substrate for METH production were available in this region till late 1980s whereas in other European countries were restricted in 1970s. In fact, the Czech Republic is the leader in prevalence of METH users, and the number of dependent individuals stays consistent for many years (EMCDDA 2010). The combinations of recreational drugs are usual in drug abusers, and ethanol (ET) as a legal substance is often consumed by addicted people. Combining ET with other substances can lead to severe pharmacokinetic or pharmacodynamic interactions. Actually, the most frequent combinations of drugs that lead to visit of the Emergency Department in U.S. in 2008 were those with ET (SAMHSA 2008).

The interactions between METH and ET have been widely studied. The experiments focused on the behavioural aspects of ET and METH combination documented, that ET accentuates the METH neurotoxicity, and both of them are evoking anxiolytic effects in rats (Chuang et al., 2011). The combination is also more potent in causing memory impairment in rats than administration of single drugs (Yamamura et al., 1992). The molecular mechanism of these behavioural effects is probably carried by different changes on dopamine and serotonin release, which are dependent not only on the substance, but may also vary between rat strains (Nishiguchi et al., 2002, Yamauchi et al., 2000). The chronic administration of METH alone could increase the ET intake in mice because of induction of long term dopaminergic toxicity, and hypodopaminergic state is described to increase the voluntary ET consumption (Gutierrez-Lopez et al., 2010).

Preclinical experiments aimed on pharmacokinetic interactions of ET and METH describe the inhibition of METH metabolism when combined with ET (Liang et al., 2012). Increase in the METH plasmatic levels is due to inhibition of METH Ndemethylation and parahydroxylation (Yamada et al., 2001) caused by ET. The similar result was confirmed in humans, too (Shimosato, 1988), whereas other clinical trial with ET and METH combination did not discover any change in METH levels among subjects (Mendelson et al., 1995). The design of the study can substantially influence results, since it was described that coincidental administration of ET and METH results in inhibition of METH metabolism, whereas the same substance is biotransformed faster in METH addicts with chronic ET ingestion (Shimosato et al., 1988).

Papers describing pharmacokinetic interaction between METH and ET are exclusively aimed on the influence of ET on the biotransformation of METH, while our recent study is addressed oppositely. We have determined the effect of 10 day long METH administration on the pharmacokinetics of ET in rats. We hypothesised that ET plasmatic levels could be influenced due to inhibitory effect of METH on cytochrome P450 2E1 enzyme, which was documented (Minarikova et al., 2006). Therefore we decided to use a relatively high but equal dose of METH as was administered in Minarikova's study. 


\section{MATERIAL AND METHODS}

\section{Animals}

The study was carried out on male Wistar albino rats weighing $200 \pm 20$ g. Animals were housed under temperature $\left(21-22^{\circ} \mathrm{C}\right)$ and humidity $(50-60 \%)$ controlled conditions. Rats were housed singly to avoid injuries in METH administered individuals in standard plastic cages with free access to water and pelleted diet.

Animals were randomly divided into two groups $(n=10)$, one of them was administered with intraperitoneal injections of METH (Sigma Chemical Co., St. Louis, USA) at one daily dose of $10.0 \mathrm{mg} / \mathrm{kg}$ for 10 consecutive days. Second group - controls, received equal volume of saline.

All procedures were approved by the Czech Central Commission for Animal Welfare.

\section{Pharmacokinetic study}

The pharmacokinetic study in the whole animal was performed on the $10^{\text {th }}$ day of METH treatment. The animals were injected either with METH or saline, and consecutively with ET intragastrically. ET (Lach-Ner s.r.o., Neratovice, CZ) was administered at the dose of $2.0 \mathrm{~g} / \mathrm{kg}$ as a $20 \%$ solution dissolved in $5 \%$ glucose, to limit the gastric irritation and supply rats with additional nutrition for the kinetic experiment. Animals were anesthetized with diethylether, and blood from plexus retrobulbaris was sampled with heparinized capillary tube in the following time intervals from ET administration: $40 \mathrm{~min}, 120 \mathrm{~min}, 210 \mathrm{~min}$, and $300 \mathrm{~min}$. Samples were allowed to clot at room temperature and were centrifuged 10 minutes at $4^{\circ} \mathrm{C}$ at $3000 \mathrm{~g}$ to obtain serum, which was frozen until analysis at $-75^{\circ} \mathrm{C}$.

\section{Sample analysis}

Gas chromatography (GC) was used to evaluate the levels of ET in samples. Analysis was performed on YL 6100GC (YL Instruments Co., Kyounggi-do, KOR) with Agilent 5062-3587 (Agilent Technologies Int., Santa Clara, USA) inlet, flame ionization detector and SLB-5ms $30 \mathrm{~m}$ × $0.25 \mathrm{~mm} \times 0.25 \mu \mathrm{m}$ (Sigma Chemical Co., St. Louis, USA) column. Analysis conditions were as follows: carrier gas nitrogen, inlet temperature $160^{\circ} \mathrm{C}$; flow $2 \mathrm{ml} / \mathrm{min}$; split $1: 30$; detector temperature $200^{\circ} \mathrm{C}$, gas flow air $300 \mathrm{ml}$, hydrogen $30 \mathrm{ml}$, make up $20 \mathrm{ml}$; total separation time $6.5 \mathrm{~min}$. Limit of detection and quantification was determined to be $0.006 \%$ and $0.009 \%$ of ET respectively. The samples were analysed in duplicates and the mean value was used for the statistical analysis. The calibration line was transformed into log line for the values close to the quantification limit.

\section{Statistical evaluation}

Obtained results were statistically analysed with Dixon's Q test to exclude outliers. Repeated measure ANOVA with Fisher post-hoc test for multiple comparisons was used for the data analysis using software Statistica 8 for Windows. Data are expressed as means \pm SD. Values of $\mathrm{p}<0.05$ were considered to be statistically significant. 


\section{RESULTS}

The levels of ET measured declined in both METH and saline treated groups during the experiment (Figure 1), but there were statistically significant differences between the values in the first two sampling intervals. The plasmatic levels of ET in rats which received METH were lower than in controls. In the $40^{\text {th }}$ minute ET values in METH animals were $0.594 \%$, $\mathrm{SD} \pm 0.303 \%$, while in the control group animals $1.618 \%$, $\mathrm{SD} \pm 0.696 \% ; \mathrm{p}<0.001$. In the $120^{\text {th }} \mathrm{min}$ in METH animals were measured values $0.189 \%$, $\mathrm{SD} \pm 0.169 \%$, in comparison to controls $0.853 \%$, $\mathrm{SD} \pm 0.665 \%$; $\mathrm{p}=0.002$. There were no statistically significant differences in the last two intervals assessed. ET concentration in the $210^{\text {th }}$ were METH $0.010 \%$, SD $\pm 0.005 \%$, control $0.331 \%$, SD $\pm 0.447 \%$, $p=0.31$. In METH animals $0.007 \%$, SD $\pm 0.001 \%$ and in control rats $0.014 \%, \mathrm{SD} \pm 0.014 \%$ o was detected.

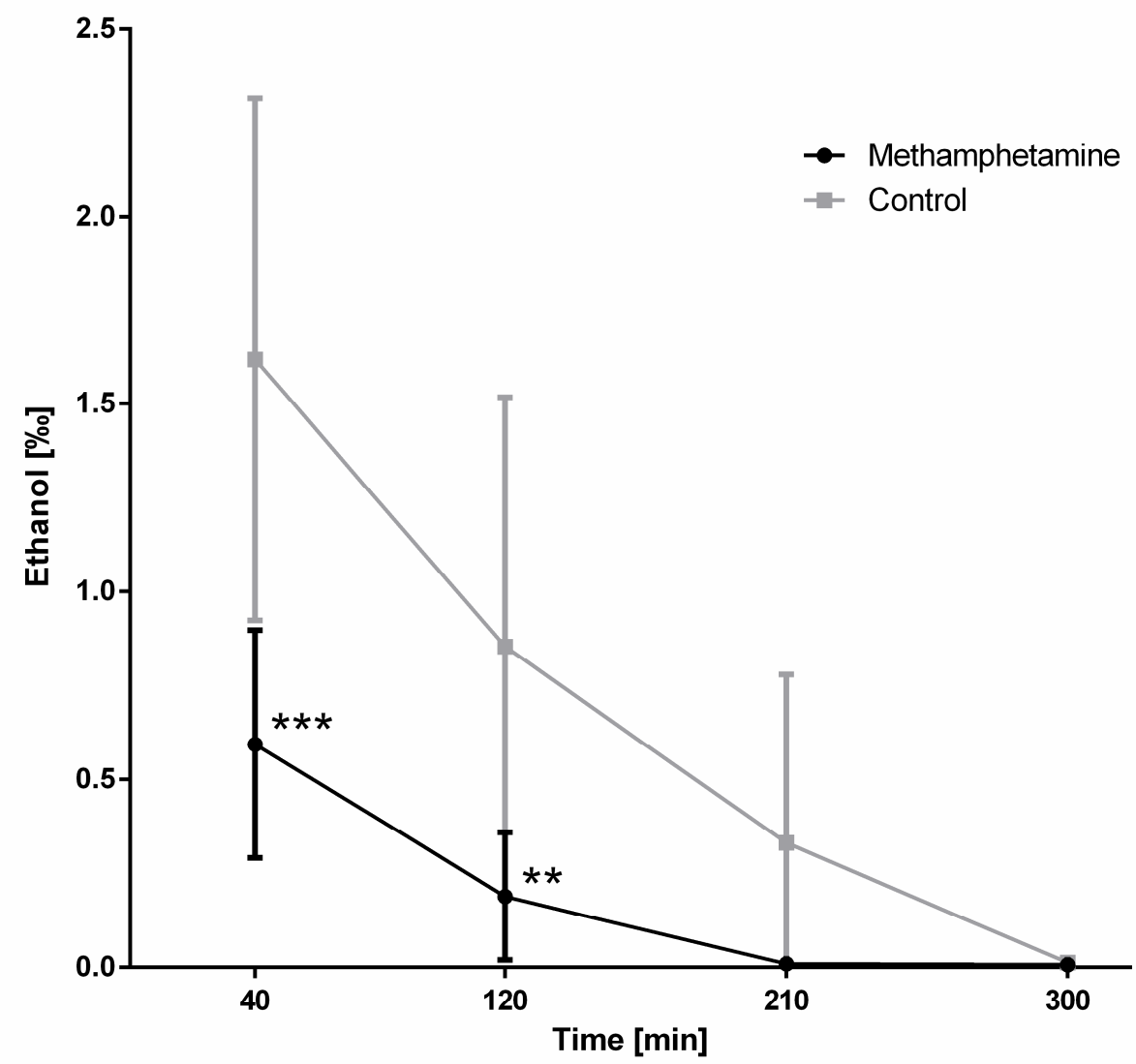

Figure 1. Ethanol concentrations [\%o] in controls and rats administered with methamphetamine $(10 \mathrm{mg} / \mathrm{kg} / \mathrm{day})$ for 10 days after single dose of ethanol $(2 \mathrm{~g} / \mathrm{kg})$. Data represents means \pm SD 


\section{DISCUSSION}

Our results did not confirm our original hypothesis of ET metabolism inhibition due to influence of METH on 2E1 enzyme. Oppositely, obtained data suggests that chronic administration of METH increased the rate of ET biotransformation. This was apparent from the lower concentrations of ET in METH administered animals than in controls. However, the METH influence was statistically significant only in the first two sampling intervals. Thus, we suppose that insignificancy of difference between groups in samples drawn on the $210^{\text {th }}$ and $300^{\text {th }}$ minutes rise from very low ET level reaching almost the detection limit of method used. As far as we know, induction of ET biotransformation by METH was not described previously unlike of opposite effect of ET on METH metabolism (Liang et al., 2012, Mendelson et al., 1995, Shimosato, 1988, Shimosato et al., 1988, Yamada et al., 2001).

We suggest that there may be considered three possible mechanisms explaining the pharmacokinetic interaction described: 1. METH decreases the bioavailability of ET; 2 . METH enhances the excretion of unchanged ET; 3. METH induces enzymes of ET biotransformation pathway.

Most of the interactions on the level of absorption are based in the change of specific carrier system activity and thus occur only in drugs using this mechanism of absorption. ET with small molecule and its physico-chemical properties is an easily diffusible compound (Holt, 1981) crossing well all biological barriers in the body. Therefore the first above-mentioned suggestion can be excluded and because of the same reasons the second one as well. The portion of unchanged ET excreted by lungs and kidneys varies from 2 to $10 \%$ (Lieber, 1997) and no specific carriers are involved.

The third possible explanation: it has to be considered that approximately $89 \%$ of METH is metabolized in rats with major metabolites 4-hydroxymethamphetamine and 4-hydroxynorephedrine (Caldwell et al., 1972). The enzymes involved in the metabolism of METH are cytochromes P450 (CYP), especially CYP2D enzymes participating in 4-hydroxylation of METH aromatic ring (Lin et al., 1995). While the major metabolic pathway of ET in rats is via alcohol dehydrogenase (ADH) with essential role of ADH-3 isoenzyme (Boleda et al., 1989), the ADH is not the only enzyme metabolizing ET. The minor metabolic pathway of ET microsomal oxidizing system represents CYP2E1 (Ronis et al., 1993). Further, it is known, that CYP2E1 is inducible and the observed effect of METH could be explained by massive increase of CYP2E1 metabolic rate. However, the induction of this enzyme is described for ethanol (McGehee et al., 1994) but not for METH. The influence of METH on CYP enzymes is disputable. There are works describing induction of CYP2D, CYP2C6 and CYP3A by METH (Dostalek et al., 2005, 2007). Nevertheless we did not document this effect in our previous studies (Zendulka et al., 2010). Same result is reported by Minarikova; moreover she documented a weak inhibitory effect of METH on CYP2E1 (Minarikova et al., 2006). This means that the induction of ET metabolism is definitely not carried by the effect of METH on CYP and thus only the possibility of ADH induction remains. The increase of ADH activity can be either in posttranslational phase by allosteric activation by METH or by genetic transcription stimulation. The question whether it is caused directly by METH or indirectly via 
dopaminergic activity of METH in the CNS and its peripheral consequences is still not answered. More studies have to be conducted to confirm or disprove our hypothesis.

\section{CONCLUSIONS}

Taken together, our results suggest that repeated pre-treatment with METH led to the decrease of ET levels in time points between minutes 0 and 120 after acute alcohol administration. According to the best of our knowledge such effect was not described before. Thus our next study will be focused on dose dependence in the actual documented effect of METH on ET metabolism.

\section{ACKNOWLEDGMENT}

This work was supported by the project "CEITEC - Central European Institute of Technology" (CZ.1.05/1.1.00/02.0068) from European Regional Development Fund.

\section{REFERENCES}

Boleda MD, Julia P, Moreno A, Pares X. Role of Extrahepatic Alcohol-Dehydrogenase in Rat Ethanol-Metabolism. Arch Biochem Biophys. 1989;274:74-81.

Caldwell J, Dring LG, Williams RT. Metabolism of [C-14]Methamphetamine in Man, Guinea-Pig and Rat. Biochem J. 1972;129:11-22.

Dostalek M, Hadasova E, Hanesova M, et al. Feet of methamphetamine on the pharmacokinetics of dextromethorphan and midazolam in rats. Eur J Drug Metab Pharmacokinet. 2005;30:195-201.

Dostalek M, Jurica J, Pistovcakova J, et al. Effect of methamphetamine on cytochrome P450 activity. Xenobiotica. 2007;37:1355-1366.

EMCDDA - European Monitoring Centre for Drugs and Drug Addiction. Problem amphetamine and methamphetamine use in Europe. 978-92-9168-450-2. (http://www.emcdda.europa.eu/attachements.cfm/att_120112_EN_EMCDDA_SI10_A mphetamines.pdf). Acessed August 28, 2012

Gutierrez-Lopez MD, Llopis N, Feng S, Barrett DA, O'Shea E, Colado MI. Involvement of 2-arachidonoyl glycerol in the increased consumption of and preference for ethanol of mice treated with neurotoxic doses of methamphetamine. $\mathrm{Br} \mathrm{J}$ Pharmacol. 2010;160:772-783. 
Holt S. Observations on the Relation between Alcohol Absorption and the Rate of Gastric-Emptying. CMAJ. 1981;124:267-277.

Chuang JY, Chang WT, Cherng CFG, Kao GS, Yu L. Repeated co-administrations of alcohol- and methamphetamine-produced anxiogenic effect could be associated with the neurotoxicity in the dentate gyrus. Journal Neural Transm. 2011;118:1559-1569.

Liang M, Liu Y, Zheng N, Ananda S, Liu L. Distribution of methamphetamine and its metabolite amphetamine in acute and subacute ethanol-methamphetamine combination abuse model rats. J Anal Toxicol. 2012;36:30-35.

Lieber CS. Ethanol metabolism, cirrhosis and alcoholism. Clinica Chimica Acta. 1997;257:59-84.

Lin LY, Kumagai Y, Hiratsuka A, et al. Cytochrome P4502D Isozymes Catalyze the 4Hydroxylation of Methamphetamine Enantiomers. Drug Metab Dispos. 1995;23:610614.

McGehee RE, Ronis MJJ, Cowherd RM, Ingelman-Sundberg M, Badger TM. Characterization of Cytochrome-P450 2E1 Induction in a Rat Hepatoma Fgc-4 Cell Model by Ethanol. Biochem Pharmacol. 1994;48:1823-1833.

Mendelson J, Jones RT, Upton R, Jacob P 3rd. Methamphetamine and ethanol interactions in humans. Clin Pharmacol Ther. 1995;57:559-568.

Minarikova V, Hadasova E, Möritz K, Scheuch E, Siegmund E. Comparison of the influence of methamphetamine and phenobarbital on the activity of hepatic microsomal monooxygenases in the rat. Homeostasis in Health and Disease. 2006;44:135-137.

Nishiguchi M, Kinoshita H, Taniguchi T, et al. Effects of chronic alcohol administration on changes of extracellular dopamine and serotonin concentration induced by methamphetamine-comparison of two different alcohol preference rat lines. Nihon Arukoru Yakubutsu Igakkai Zasshi. 2002;37:555-576.

Ronis MJJ, Huang JA, Crouch J, et al. Cytochrome-P450 Cyp-2E1 Induction during Chronic Alcohol Exposure Occurs by a 2-Step Mechanism Associated with BloodAlcohol Concentrations in Rats. J Pharmacol Exp Ther. 1993;264:944-950.

SAMHSA - Substance Abuse and Mental Health Services Administration, Office of Applied Studies. Drug Abuse Warning Network, 2006: National Estimates of DrugRelated Emergency Department Visits. DAWN Series D-30, DHHS Publication No. (SMA) 08-4339, Rockville, MD, 2008. 
Shimosato K. Urinary excretion of p-hydroxylated methamphetamine metabolites in man. II. Effect of alcohol intake on methamphetamine metabolism. Pharmacol Biochem Behav. 1988;29:733-740.

Shimosato K, Oda H, Ohmae M, Tomita M, Doi Y. Biphasic effects of alcohol drinking on methamphetamine metabolism in man. Alcohol. 1988;23:351-357.

Yamada T, Hayashida M, Nihira M. Influence of ethanol on metabolism of methamphetamine in rats including hair analysis. Nihon Arukoru Yakubutsu Igakkai Zasshi. 2001;36:182-200.

Yamamura T, Hishida S, Hatake K, Taniguchi T, Ouchi H. Effects of methamphetamine and ethanol on learning and brain neurotransmitters in rats. Pharmacol Biochem Behav. 1992;42:389-400.

Yamauchi J, Marukawa S, Hishida S. Simultaneous administration of ethanol emphasizes the effect of methamphetamine on central nervous system in rat with high alcohol preference. Nihon Arukoru Yakubutsu Igakkai Zasshi. 2000;35:28-47.

Zendulka O, Jurica J, Sabova M, Sulcova M. Methamphetamine does not influence the metabolic activity of CYP 1A2, 2C6 and 2D2 isoenzymes in the animal study. Activitas Nervosa Superior Rediviva. 2010;52:269-271.

Registered: $\quad$ September 15, 2012

Accepted: $\quad$ November 7, 2012

PharmDr. Ondřej Zendulka, PhD. Masaryk University in Brno Faculty of Medicine Department of Pharmacology Czech Republic zendulka@med.muni.cz

\section{VLIV METAMFETAMINU NA BIOTRANSFORMACI ETHANOLU - PILOTNÍ STUDIE}

${ }^{1,2}$ Zendulka, O. $-{ }^{1,2}$ Sabová, M. $-{ }^{1,2}$ Juřica, J. $-{ }^{3}$ Machalíček, M. $-{ }^{3}$ Švéda, P. - ${ }^{3}$ Farková, M. 'Šulcová, $A$.

${ }^{1}$ Masarykova Univerzita Brno, Středoevropský technologický institute, Výzkumní skupina experimentální a aplikované neuropsychofarmakologie, ${ }^{2}$ Masarykova Univerzita Brno, Lékařská fakulta, Farmakologický ústav, ${ }^{3}$ Masarykova univerzita Brno, Př́rodovědecká fakulta, Ústav chemie

Metamfetamin je jednou z nejčastěji zneužívaných drog v regionu Střední Evropy a velmi často je jeho užívání kombinováno s požíváním alkoholu. $\mathrm{V}$ minulosti byly popsány rozličné interakce mezi těmito dvěma látkami včetně vlivu ethanolu na biotransformaci metamfetaminu. Cíl této práce je přesně opačný, tedy popsat vliv metamfetaminu na biotransformaci etanolu u potkana. Metamfetamin $(10 \mathrm{mg} / \mathrm{kg} / \mathrm{den})$ byl zvíratům aplikován ve formě i.p. injekcí 10 dní. Ethanol (2 
$\mathrm{g} / \mathrm{kg}$ intragastricky) byl podán kontrolním i metamfetaminem premedikovaným zvířatům společně s poslední dávkou metamfetaminu. Následně byl proveden farmakokinetický experiment na celém zvířeti s odběrem vzorků krve v následujících časových intervalech od aplikace ethanolu: 40, 120, 210 a 300 minut.

Hladiny ethanolu v plazmě stanovené metodou plynové chromatografie byly signifikantně nižší u metamfetaminem premedikovaných zvířat než u kontrol ve 40. a 120. minutě experimentu, zatímco v následujících dvou časových intervalech byl rozdíl nesignifikantní. Naše výsledky naznačují, že chronicky aplikovaný metamfetamin zrychluje biotransformaci ethanolu. Domníváme se, že tento efekt je zprostředkován prostřednictvím alkoholdehydrogenázy bud' zvýšení genové exprese nebo alosterickou modulací tohoto enzymu vlivem metamfetaminu. K ověření nebo vyvrácení naší hypotézy je nutné provést další studie.

Acta Fac. Pharm. Univ. Comen. LIX, 2012, (2), p. 63-71. 